\title{
Catalytic Hydroxylation of Polypropylenes
}

Chulsung Bae ${ }^{1,8}$ John F. Hartwig, ${ }^{, \dagger}$ Nicole K. Boaen,${ }^{2}$ Rachael O. Long, ${ }^{\dagger}$ Kelly S. Anderson,

\author{
Marc A. Hillmyer,* \\ Department of Chemistry, Yale University, P.O. Box 208107, New Haven, Connecticut 06520- \\ 8107, and Department of Chemistry, University of Minnesota, 207 Pleasant Street SE, \\ Minneapolis, Minnesota 55455-0431
}

\section{Supporting Information}

\begin{abstract}
Page
Experimental Section

S2
\end{abstract}

Figure S1. ${ }^{13} \mathrm{C}$ APT NMR spectra of isotactic polypropylene and $1 \%$

hydroxylated isotactic polypropylene

S10

Yale University

$\S$ Current address: Department of Chemistry, University of Nevada Las Vegas, 4505 Maryland Parkway, Las Vegas, Nevada, 89154-4003

* To whom correspondence should be addressed. Email addresses: john.hartwig@yale.edu; hillmyer@chem.umn.edu

2 University of Minnesota 


\section{Experimental Section}

General. Unless otherwise specified, all reagents were purchased from commercial suppliers and used without further purification. aPP-2 and iPP-1 were obtained from Dow Chemical Company and used as supplied. sPP-1, a gift from ATOFINA Petrochemicals Inc., was used as supplied. iPP-2 and sPP-2 were purchased from Aldrich Chemical Co. and used as supplied. PEP and aPP-1 were synthesized according to literature methods. ${ }^{1,2}$ Bis(pinacolato)diboron $\left(\mathrm{B}_{2} \operatorname{pin}_{2}\right)$ was obtained from Frontier Scientific Co. and was used without further purification. $\left(\mathrm{Cp}^{*} \mathrm{RhCl}_{2}\right)_{2},{ }^{3} \mathrm{Cp} * \mathrm{Rh}\left(\eta^{4}-\mathrm{C}_{6} \mathrm{Me}_{6}\right),{ }^{4}$ and $\mathrm{Cp} * \mathrm{Rh}\left(\mathrm{C}_{2} \mathrm{H}_{4}\right)_{2}{ }^{5}$ were synthesized according to literature methods. The borylation reactions were assembled in an inert atmosphere glove box. For functionalized polypropylenes and PEP, ${ }^{1} \mathrm{H}$ NMR spectra were acquired at $400 \mathrm{MHz}$; protondecoupled ${ }^{13} \mathrm{C}$ NMR spectra were obtained at $125 \mathrm{MHz}$, and ${ }^{11} \mathrm{~B}$ NMR spectra were obtained at $80 \mathrm{MHz} .{ }^{1} \mathrm{H}$ and ${ }^{13} \mathrm{C}$ chemical shifts are referenced to TMS, and ${ }^{11} \mathrm{~B}$ chemical shifts are reported relative to an external standard of $\mathrm{BF}_{3}-\mathrm{Et}_{2} \mathrm{O}$; resonances downfield of the standard are reported as positive.

For the polymerization of graft copolymers and blends, the following materials and methods were employed. Isotactic polypropylene $\left(M_{n}=\right.$ ca. $\left.97 \mathrm{~kg} / \mathrm{mol}\right)$ and polycaprolactone $\left(M_{n}=\right.$ ca. 80 $\mathrm{kg} / \mathrm{mol}$, according to manufacturer; $\mathrm{M}_{\mathrm{n}}=101 \mathrm{~kg} / \mathrm{mol}$, as measured by $\mathrm{SEC}$ ) were purchased from Aldrich and used directly in the melt blends. $\varepsilon$-caprolactone was purchased from Aldrich, dried over calcium hydride overnight, collected by vacuum distillation, and stored in a dry box. Triethylaluminum (1.0 M in heptane) was purchased from Aldrich and stored in a dry box. Acidic water (20\%) was prepared using $37 \% \mathrm{HCl}$ and distilled water. Tetrahydrofuran (THF) was purified using a solvent purification system. ${ }^{6}$ 
${ }^{1} \mathrm{H}$ and ${ }^{13} \mathrm{C}$ NMR spectra of graft copolymers were recorded on a Varian 300-VXR spectrometer and a Unity VAC-300 autosampler instrument. NMR samples were prepared in deuterated chloroform $(0.010 \mathrm{~g} / \mathrm{mL})$ (Cambridge Isotope Laboratories), and occasionally a heat gun was used to dissolve the polymer. Some NMR experiments were conducted at $50{ }^{\circ} \mathrm{C}$ as stated in the figure captions.

Size exclusion chromatography (SEC) analyses were obtained using a Hewlett Packard Series 1100 liquid chromatograph equipped with three Jordi polydivinylbenzene columns of $10^{4}, 10^{2}$, and $500 \AA$ and a HP $1047 \mathrm{~A}$ refractive index detector at $35^{\circ} \mathrm{C}$. Tetrahydrofuran was the mobile phase and the flow rate was set at $1.0 \mathrm{~mL} / \mathrm{min}$. High temperature size exclusion chromatography (SEC) analyses were obtained using a Polymer Laboratories GPC-220 high temperature liquid chromatograph equipped with three Polymer Laboratories gel $10 \mu \mathrm{m}$ Mixed-B columns and a refractive index detector at $140{ }^{\circ} \mathrm{C} .1,2,4$-trichlorobenzene was the mobile phase and the flow rate was set at $1.0 \mathrm{~mL} / \mathrm{min}$. Both instruments were calibrated using polystyrene standards. Differential Scanning Calorimetry (DSC) measurements were made on a Pyris instrument using temperature scan from -100 to $160^{\circ} \mathrm{C}$ at a scan rate of $10{ }^{\circ} \mathrm{C} / \mathrm{min}$ for graft copolymers, and on a TA Q1000 autosampler instrument using temperature scan from -100 to $200{ }^{\circ} \mathrm{C}$ at a scan rate of $20^{\circ} \mathrm{C} / \mathrm{min}$ for melt blends.

Melt blends (20 g scale) were prepared on a Haake Rheomix 600 batch mixer (ThermoHaake, Karlsruhe, Germany) with 15 minutes mixing at $190^{\circ} \mathrm{C}$ and $50 \mathrm{rpm}$.

Mechanical properties of the materials were assessed by the notched Izod impact test and tensile test. The sample specimens (impact test bars: 12.7 X $63.5 \times 3.2 \mathrm{~mm}$, tensile test dog bone bars: size dimensions $50.1 \mathrm{~mm}$ X $1.5 \mathrm{~mm}$ with gauge length $21.5 \mathrm{~mm}$ and gauge width $5.0 \mathrm{~mm}$ ) were prepared by compression molding the blends using the following procedure: melted for 7 
minutes at $190{ }^{\circ} \mathrm{C}$, and pressed for 2 minutes each at $50,250,500$, and 1000 lbs at $190{ }^{\circ} \mathrm{C}$, cooled to $100{ }^{\circ} \mathrm{C}$ holding at $1000 \mathrm{lbs}$, and finally cooling to room temperature. The impact tests were performed on a Resil 25 (CEAST, Pianezza, Italy) at room temperature with a notch depth cut at $2.54 \mathrm{~cm}$, according to ASTM D256. The impact energy was determined by a calculation whereby the total energy required to break the sample was divided by the thickness of the impact bar. The tensile tests were performed on an Instron 5550 instrument with a pull rate of 10 $\mathrm{mm} / \mathrm{min}$ according to ASTM D1708. A minimum of three samples were usually tested for each blend.

Scanning electron microscopy was performed on platinum-coated (50 ̊) cryofractured specimens using a Hitachi S-800 scanning electron microscope (Hitachi, Tokyo, Japan) with an accelerating voltage of $5 \mathrm{kV}$.

\section{Typical procedure for borylation of poly(ethylene-alt-propylene): Synthesis of PEP-Bpin.}

In a $\mathrm{N}_{2}$ filled glove box, a mixture of PEP (289 mg, $\left.4.12 \mathrm{mmol}\right), \mathrm{B}_{2} \mathrm{pin}_{2}(52.0 \mathrm{mg}, 0.205 \mathrm{mmol})$, $\mathrm{Cp} * \mathrm{Rh}\left(\eta^{4}-\mathrm{C}_{6} \mathrm{Me}_{6}\right)(4.0 \mathrm{mg}, 0.010 \mathrm{mmol})$, and a magnetic stir bar were placed into a vial equipped with a Teflon-lined septum. The vial was removed from the box and placed in an oil bath at $185^{\circ} \mathrm{C}$ for $30 \mathrm{~h}$. After cooling to room temperature, the mixture was dissolved in hexane $(10 \mathrm{~mL})$ and filtered through a short plug of Celite. The filtrate was concentrated and purified by column chromatography on silica gel (gradient of hexane $(100 \%)$ to hexane/ethyl acetate $(2: 1)$ as eluent) to give two fractions. Evaporation of solvent from one fraction gave the predominantly borylated polymer PEP-Bpin (202 mg, $70 \%$ ), and evaporation of solvent from the second gave recovered unfunctionalized polymer $(96 \mathrm{mg}):{ }^{1} \mathrm{H}$ NMR of functionalized material $(400 \mathrm{MHz}$, $\left.\mathrm{CDCl}_{3}\right) \delta 0.82\left(\mathrm{~d}, \mathrm{~J}=6.6 \mathrm{~Hz}, \mathrm{CH}_{3}\right), 1.00-1.12\left(\mathrm{br},-\mathrm{CH}_{2} \mathrm{CH}_{2} \mathrm{CH}\left(\mathrm{CH}_{3}\right) \mathrm{CH}_{2}-\right), 1.23\left(\mathrm{~s}, \mathrm{BOCCH}_{3}\right)$, 1.25 (br, $\left.-\mathrm{CH}_{2} \mathrm{CH}_{2} \mathrm{CH}\left(\mathrm{CH}_{3}\right) \mathrm{CH}_{2}-\right), 1.35$ (br, $\left.\mathrm{CH}\right) ;{ }^{13} \mathrm{C} \mathrm{NMR}\left(125 \mathrm{MHz}, \mathrm{CDCl}_{3}\right) \delta 19.5-20.3$ 
$\left(\mathrm{CH}_{3}\right), \quad 25.2 \quad\left(-\mathrm{CH}_{2} \mathrm{CH}_{2} \mathrm{CH}\left(\mathrm{CH}_{3}\right) \mathrm{CH}_{2^{-}} \quad\right.$ and $\left.\quad \mathrm{BOCCH}_{3}\right), \quad 33.6 \quad(\mathrm{CH}), \quad 37.7-38.0 \quad(-$ $\left.\mathrm{CH}_{2} \mathrm{CH}_{2} \mathrm{CH}\left(\mathrm{CH}_{3}\right) \underline{\mathrm{CH}_{2}-}\right), 83.1\left(\mathrm{BOCCH}_{3}\right) ;{ }^{11} \mathrm{~B} \mathrm{NMR}\left(80 \mathrm{MHz}, \mathrm{CDCl}_{3}\right) \delta 34.0$ (br).

Typical procedure for oxidation of boron functionalized poly(ethylene-alt-propylene): Synthesis of PEP-OH. The PEP-Bpin (154 mg) was dissolved in THF $(25 \mathrm{~mL})$ in a $100 \mathrm{~mL}$ flask and cooled to $0{ }^{\circ} \mathrm{C}$ using an ice bath. A mixture of $\mathrm{H}_{2} \mathrm{O}(10 \mathrm{~mL}), 1 \mathrm{~N} \mathrm{NaOH}(1 \mathrm{~mL})$, and 30 $\% \mathrm{H}_{2} \mathrm{O}_{2}(0.2 \mathrm{~mL})$ was added slowly to the polymer solution at $0{ }^{\circ} \mathrm{C}$. The resulting solution was stirred at room temperature for $15 \mathrm{~h}$. The solution was concentrated with a rotary evaporator, and $\mathrm{H}_{2} \mathrm{O}(35 \mathrm{~mL})$ was added. The solution was neutralized with $1 \mathrm{~N} \mathrm{HCl}$. The solution was extracted with a mixture of hexanes and ethyl acetate and washed with $\mathrm{H}_{2} \mathrm{O}$. The aqueous phase was extracted with a mixture of hexanes and ethyl acetate. The organic solutions were combined, dried over $\mathrm{MgSO}_{4}$, filtered, and concentrated. The residue was purified by column chromatography on silica gel (gradient of hexane (100\%) to hexane/ethyl acetate $(2: 1)$ as eluent). Evaporation of solvent gave PEP-OH $(131 \mathrm{mg}, 60 \%$ overall yield based on polymer weight from PEP): ${ }^{1} \mathrm{H}$ NMR $\left(400 \mathrm{MHz}, \mathrm{CDCl}_{3}\right) \delta 0.82\left(\mathrm{~d}, \mathrm{~J}=6.3 \mathrm{~Hz}, \mathrm{CH}_{3}\right), 1.00-1.12(\mathrm{br},-$ $\left.\mathrm{C}_{2} \mathrm{CH}_{2} \mathrm{CH}\left(\mathrm{CH}_{3}\right) \mathrm{CH}_{2}-\right), 1.25$ (br, - $\left.\mathrm{CH}_{2} \mathrm{CH}_{2} \mathrm{CH}\left(\mathrm{CH}_{3}\right) \mathrm{C}_{2}-\right), 1.35$ (br, $\left.\mathrm{CH}\right), 3.55$ (d, J = $5.4 \mathrm{~Hz}$, $\left.\mathrm{C}_{2} \mathrm{OH}\right) ;{ }^{13} \mathrm{C}$ NMR $\left(125 \mathrm{MHz}, \mathrm{CDCl}_{3}\right) \delta 19.5-20.3\left(\mathrm{CH}_{3}\right), 25.2\left(-\mathrm{CH}_{2} \mathrm{CH}_{2} \mathrm{CH}\left(\mathrm{CH}_{3}\right) \mathrm{CH}_{2}-\right), 33.6$ (CH), 37.7-38.0 (- $\left.\mathrm{CH}_{2} \mathrm{CH}_{2} \mathrm{CH}\left(\mathrm{CH}_{3}\right) \mathrm{CH}_{2}{ }^{-}\right), 65.7\left(\mathrm{CH}_{2} \mathrm{OH}\right)$.

Typical procedure for borylation of model atactic polypropylene: Synthesis of aPP-1Bpin. aPP-1-Bpin was prepared by the similar procedure of PEP-Bpin using aPP-1 (595 mg, $14.2 \mathrm{mmol}), \mathrm{B}_{2} \mathrm{pin}_{2}(360 \mathrm{mg}, 1.42 \mathrm{mmol})$, and $\mathrm{Cp} * \mathrm{Rh}\left(\eta^{4}-\mathrm{C}_{6} \mathrm{Me}_{6}\right)(28.4 \mathrm{mg}, 0.0709 \mathrm{mmol})$, except the vial was placed in an oil bath at $200{ }^{\circ} \mathrm{C}$ for $24 \mathrm{~h}$. Purification of the crude product by column chromatography on silica gel (gradient of hexane (100\%) to hexane/ethyl acetate (2:1) as eluent) gave two fractions. Evaporation of solvent from one fraction gave the predominantly 
borylated product aPP-1-Bpin (595 mg, $96 \%)$, and evaporation of solvent from the second fraction gave unfunctionalized polymer $(26 \mathrm{mg}, 4 \%):{ }^{1} \mathrm{H} \mathrm{NMR}\left(400 \mathrm{MHz}, \mathrm{CDCl}_{3}\right) \delta 0.81-1.24$ (br, $\mathrm{CH}_{3}$ and $\left.\mathrm{CH}_{2}\right), 1.23\left(\mathrm{~s}, \mathrm{BOCCH}_{3}\right), 1.58(\mathrm{br}, \mathrm{CH}) ;{ }^{13} \mathrm{C} \mathrm{NMR}\left(125 \mathrm{MHz}, \mathrm{CDCl}_{3}\right) \delta 19.5-21.0$ $\left(\mathrm{CH}_{3}\right), 24.8\left(\mathrm{BOC} \mathrm{H}_{3}\right), 27.2(\mathrm{CH}), 44.0-47.3\left(\mathrm{CH}_{2}\right), 82.7\left(\mathrm{BOCCH}_{3}\right) ;{ }^{11} \mathrm{~B}$ NMR (80 MHz, $\left.\mathrm{CDCl}_{3}\right) \delta 33.8(\mathrm{br})$

Typical procedure for oxidation of boron functionalized model atactic polypropylene: Synthesis of aPP-1-OH. The borylated polymer aPP-1-Bpin (186 mg) was oxidized in THF (40 $\mathrm{mL}$ ) by the similar procedure of PEP-OH using a mixture of $1 \mathrm{~N} \mathrm{NaOH}(1.5 \mathrm{~mL})$ and $30 \% \mathrm{H}_{2} \mathrm{O}_{2}$ $(0.5 \mathrm{~mL})$. After neutralization with $1 \mathrm{~N} \mathrm{HCl}$, the precipitated polymer was filtered, dissolved in $40 \mathrm{~mL}$ of a 1:1 ratio of hexane and ethyl acetate, and washed with $\mathrm{H}_{2} \mathrm{O}$. The aqueous phase was extracted with a mixture of hexanes and ethyl acetate. The organic solutions were combined, dried over $\mathrm{MgSO}_{4}$, filtered, and concentrated. Purification of product by column chromatography on silica gel (gradient of hexane $(100 \%)$ to hexane/ethyl acetate $(2: 1)$ as eluent) gave the hydroxylated model atactic polypropylene aPP-1-OH $(130 \mathrm{mg}, 73 \%$ overall yield based on polymer weight from aPP-1): ${ }^{1} \mathrm{H} \mathrm{NMR}\left(400 \mathrm{MHz}, \mathrm{CDCl}_{3}\right) \delta 0.82-1.28\left(\mathrm{br}, \mathrm{CH}_{3}\right.$ and $\left.\mathrm{CH}_{2}\right), 1.59$ (br, CH), $3.51\left(\mathrm{br}, \mathrm{CH}_{2} \mathrm{OH}\right) ;{ }^{13} \mathrm{C}$ NMR (125 MHz, $\left.\mathrm{CDCl}_{3}\right) \delta$ 19.6-21.0 $\left(\mathrm{CH}_{3}\right), 27.3(\mathrm{CH})$, 44.0-47.3 $\left(\mathrm{CH}_{2}\right), 66.3\left(\mathrm{CH}_{2} \mathrm{OH}\right)$.

Typical procedure for borylation of commercial atactic polypropylene: Synthesis of aPP2-Bpin. aPP-2-Bpin was prepared by a procedure similar to the preparation of PEP-Bpin. aPP-2 (470 mg, $11.2 \mathrm{mmol}), \mathrm{B}_{2} \operatorname{pin}_{2}(142 \mathrm{mg}, 0.560 \mathrm{mmol})$, and $\mathrm{Cp} * \mathrm{Rh}\left(\eta^{4}-\mathrm{C}_{6} \mathrm{Me}_{6}\right)(11 \mathrm{mg}, 0.028$ mmol) were heated in a vial that was placed in an oil bath at $200{ }^{\circ} \mathrm{C}$ for $36 \mathrm{~h}$. After cooling to room temperature, the polymer was dissolved in hexane $(10 \mathrm{~mL})$ and the resulting solution was filtered through a short plug of Celite and then through a short plug of silica gel. Evaporation of 
solvent from the filtrate gave brown solid. The solid was dissolved in hexane $(2 \mathrm{~mL})$ and cold $\mathrm{MeOH}(15 \mathrm{~mL})$ was added to precipitate the borylated polymer as brown sticky solid. Evaporation of the solvents under vacuum gave a brown solid (445 mg, $95 \%$ ): ${ }^{1} \mathrm{H}$ NMR (400 $\left.\mathrm{MHz}, \mathrm{CDCl}_{3}\right) \delta$ 0.81-1.35 (br, $\mathrm{CH}_{3}$ and $\left.\mathrm{CH}_{2}\right), 1.23\left(\mathrm{~s}, \mathrm{BOCCH}_{3}\right), 1.58(\mathrm{br}, \mathrm{CH}),{ }^{13} \mathrm{C}$ NMR $(100$ $\left.\mathrm{MHz}, \mathrm{CDCl}_{3}\right) \delta$ 19.3-21.3 $\left(\mathrm{CH}_{3}\right), 24.8\left(\mathrm{BOCCH}_{3}\right), 27.2(\mathrm{CH}), 44.0-47.2\left(\mathrm{CH}_{2}\right), 82.6\left(\mathrm{BOCCH}_{3}\right)$; ${ }^{11} \mathrm{~B}$ NMR $\left(80 \mathrm{MHz}, \mathrm{CDCl}_{3}\right) \delta 34.2(\mathrm{br})$.

\section{Typical procedure for oxidation of boron functionalized commercial atactic} polypropylene: Synthesis of aPP-2-OH. The aPP-2-Bpin (274 mg) was oxidized in THF (50 $\mathrm{mL}$ ) by a procedure similar to the preparation of PEP-OH. The polymer was oxidized in a mixture of $1 \mathrm{~N} \mathrm{NaOH}(1.5 \mathrm{~mL})$ and $30 \% \mathrm{H}_{2} \mathrm{O}_{2}(0.5 \mathrm{~mL})$. After stirring the homogeneous solution for $13 \mathrm{~h}$, the solution was concentrated in a rotary evaporator to precipitate the polymer. After addition of $\mathrm{H}_{2} \mathrm{O}(20 \mathrm{~mL})$ followed by neutralization of the aqueous solution with $1 \mathrm{~N} \mathrm{HCl}$, the polymer was isolated by filtration. The solid was dissolved in $25 \mathrm{~mL}$ of a 1:1 mixture of hexane and ethyl acetate and washed with $\mathrm{H}_{2} \mathrm{O}$. The aqueous phase was extracted with a mixture of hexanes and ethyl acetate. The organic solutions were combined, dried over $\mathrm{MgSO}_{4}$, filtered, and concentrated. The solid was dissolved in hexane and filtered though a short plug of silica gel, eluting with $5 \mathrm{~mL}$ of a 1:6 mixture of ethyl acetate and hexane followed by $5 \mathrm{~mL}$ of a 1:2 mixture of ethyl acetate and hexane. Evaporation of the solvents gave the hydroxylated atactic polypropylene aPP-2-OH (257 mg, $89 \%$ overall yield based on polymer weight from aPP-2). ${ }^{1} \mathrm{H}$ NMR (400 MHz, $\left.\mathrm{CDCl}_{3}\right) \delta 0.82-1.38\left(\mathrm{br}, \mathrm{CH}_{3}\right.$ and $\left.\mathrm{CH}_{2}\right), 1.58(\mathrm{br}, \mathrm{CH}), 3.51\left(\mathrm{br}, \mathrm{C}_{2} \mathrm{OH}\right) ;{ }^{13} \mathrm{C}$ NMR (125 MHz, $\left.\mathrm{CDCl}_{3}\right) \delta$ 19.2-21.0 $\left(\mathrm{CH}_{3}\right), 27.3(\mathrm{CH}), 44.4-47.2\left(\mathrm{CH}_{2}\right), 66.3\left(\mathrm{CH}_{2} \mathrm{OH}\right)$.

Procedure for large-scale borylation of isotactic polypropylene: Synthesis of iPP-1-Bpin. In a $\mathrm{N}_{2}$-filled glove box, a mixture of iPP-1 (77.9 g, $\left.1.86 \mathrm{~mol}\right), \mathrm{B}_{2} \mathrm{pin}_{2}(23.6 \mathrm{~g}, 92.8 \mathrm{mmol})$, 
$\mathrm{Cp} * \mathrm{Rh}\left(\eta^{4}-\mathrm{C}_{6} \mathrm{Me}_{6}\right)(1.86 \mathrm{~g}, 4.64 \mathrm{mmol})$, and a magnetic stirring bar were placed in a $1 \mathrm{~L}$ flask equipped with a reflux condenser and an $\mathrm{N}_{2}$ inlet. The flask was removed from the box and placed in an oil bath at $200{ }^{\circ} \mathrm{C}$ for $36 \mathrm{~h}$ under $\mathrm{N}_{2}$. After cooling to room temperature, the mixture was dissolved in hot toluene $(600 \mathrm{~mL})$, and the toluene solution was added to cold methanol $(\sim 2.2 \mathrm{~L})$ to precipitate the polymer. The polymer was filtered and dried in vacuo at $70{ }^{\circ} \mathrm{C}$ overnight. The borylated polymer was isolated as a white solid (80.8 g): ${ }^{1} \mathrm{H}$ NMR (400 MHz, $\left.\mathrm{CDCl}_{3}\right) \delta 0.84\left(\mathrm{~d}, \mathrm{~J}=6.0 \mathrm{~Hz}, \mathrm{CH}_{3}\right.$ and $\left.\mathrm{CH}_{2}\right), 1.19\left(\mathrm{~m}, \mathrm{CH}_{2}\right), 1.23\left(\mathrm{~s}, \mathrm{BOCCH}_{3}\right), 1.57($ sextet, $\mathrm{J}=$ $6.2 \mathrm{~Hz}, \mathrm{CH}) ;{ }^{13} \mathrm{C} \mathrm{NMR}\left(125 \mathrm{MHz}, \mathrm{CDCl}_{3}, 50{ }^{\circ} \mathrm{C}\right) \delta 21.6\left(\mathrm{CH}_{3}\right), 25.0\left(\mathrm{BOCCH}_{3}\right), 28.2(\mathrm{CH}), 45.8$ $\left(\mathrm{CH}_{2}\right), 82.7\left(\mathrm{BOCCH}_{3}\right) ;{ }^{11} \mathrm{~B} \mathrm{NMR}\left(80 \mathrm{MHz}, \mathrm{CDCl}_{3}\right) \delta 34.2$ (br).

\section{Procedure for large-scale oxidation of boron functionalized isotactic polypropylene:} Synthesis of iPP-1-OH. The iPP-1-Bpin (39.6 g) was dissolved in THF (2.5 L) in a 5 L flask equipped with a mechanical stirrer. The solution was cooled to $0{ }^{\circ} \mathrm{C}$ using an ice bath and a mixture of $1 \mathrm{~N} \mathrm{NaOH}(400 \mathrm{~mL})$ and $30 \% \mathrm{H}_{2} \mathrm{O}_{2}(300 \mathrm{~mL})$ was added slowly at $0{ }^{\circ} \mathrm{C}$. The resulting suspension was stirred at room temperature for $24 \mathrm{~h}$. The solution was concentrated by rotary evaporation and neutralized with $1 \mathrm{~N} \mathrm{HCl}$. Addition of methanol (400 mL) generated a white suspension that was stirred for $1 \mathrm{~h}$. The solid was filtered, and washed with $\mathrm{H}_{2} \mathrm{O}(3 \times 1 \mathrm{~L})$ and methanol (2 x $500 \mathrm{~mL})$. The polymer was air-dried and dissolved in hot toluene $(300 \mathrm{~mL})$. Cold methanol $(1 \mathrm{~L})$ was added to the toluene solution to precipitate the material. The solid was filtered and dried in vacuo at $70{ }^{\circ} \mathrm{C}$ overnight. The hydroxylated polymer was isolated as a white solid (36.9 g, $97 \%$ yield based on polymer weight from iPP-1): ${ }^{1} \mathrm{H}$ NMR (400 $\mathrm{MHz}, \mathrm{CDCl}_{3}$ ) $\delta 0.84\left(\mathrm{~d}, \mathrm{~J}=6.4 \mathrm{~Hz}, \mathrm{CH}_{3}\right.$ and $\left.\mathrm{CH}_{2}\right), 1.20\left(\mathrm{~m}, \mathrm{CH}_{2}\right), 1.58($ sextet, $\mathrm{J}=6.4 \mathrm{~Hz}, \mathrm{CH}), 3.51(\mathrm{~d}, \mathrm{~J}=$ $\left.5.1 \mathrm{~Hz}, \mathrm{CH}_{2} \mathrm{OH}\right) ;{ }^{13} \mathrm{C} \mathrm{NMR}\left(125 \mathrm{MHz}, \mathrm{CDCl}_{3}, 50{ }^{\circ} \mathrm{C}\right) \delta 21.2\left(\mathrm{CH}_{3}\right), 28.2(\mathrm{CH}), 36.3(-$ 
$\left.\mathrm{CH}_{2} \underline{\mathrm{CH}}\left(\mathrm{CH}_{2} \mathrm{OH}\right) \mathrm{CH}_{2}-\right), 39.9\left(-\mathrm{CH}_{2} \mathrm{CH}\left(\mathrm{CH}_{2} \mathrm{OH}\right) \underline{\mathrm{CH}}_{2}^{-}\right), 45.9\left(\mathrm{CH}_{2}\right), 67.3\left(\mathrm{CH}_{2} \mathrm{OH}\right)$. Anal. Calc'd for $\mathrm{C}_{3} \mathrm{H}_{6} \mathrm{O}_{0.13}: \mathrm{C}, 85.20 ; \mathrm{H}, 14.19$; Found: $\mathrm{C}: 84.47 \mathrm{H}: 14.39$.

Functionalized syndiotactic polypropylene. Both borylated and hydroxylated syndiotactic polypropylenes were prepared in a small scale according to the general procedure described for the borylation and hydroxylation of isotactic polypropylene. sPP-1-OH: ${ }^{1} \mathrm{H}$ NMR (400 MHz, $\left.\mathrm{CDCl}_{3}\right) \delta 0.80\left(\mathrm{~d}, \mathrm{~J}=6.8 \mathrm{~Hz}, \mathrm{CH}_{3}\right), 1.00\left(\mathrm{t}, \mathrm{J}=6.8 \mathrm{~Hz}, \mathrm{CH}_{2}\right), 1.58$ (sextet, $\left.\mathrm{J}=6.6 \mathrm{~Hz}, \mathrm{CH}\right), 3.52$ $\left(\mathrm{d}, \mathrm{J}=5.0 \mathrm{~Hz}, \mathrm{CH}_{2} \mathrm{OH}\right) ;{ }^{13} \mathrm{C} \mathrm{NMR}\left(125 \mathrm{MHz}, \mathrm{CDCl}_{3}\right) \delta 20.0\left(\mathrm{CH}_{3}\right), 27.6(\mathrm{CH}), 46.6\left(\mathrm{CH}_{2}\right), 66.1$ $\left(\mathrm{CH}_{2} \mathrm{OH}\right)$.

Synthesis of isotactic polypropylene-graft-polycaprolactone (iPP-g-PCL). Procedure ${ }^{6,62}$ for entry 3 in Table 4: iPP-1-OH, $\mathrm{AlEt}_{3}, \mathrm{THF}$, and a magnetic stir bar were charged into a high pressure glass reactor in the dry box and the reactor was sealed with a Teflon screw cap. Outside the dry box, the reactor was heated at $70{ }^{\circ} \mathrm{C}$ for $2 \mathrm{~h}$. The reactor was allowed to cool. CL was added in the dry box, and the reactor was sealed and removed. The reactor was heated at $70{ }^{\circ} \mathrm{C}$ outside the dry box for $20 \mathrm{~h}$. The reactor was allowed to cool to room temperature before approximately $4 \mathrm{~mL}$ of acidic water $(20 \%)$ was added to terminate the reaction. The reactor was stirred for $1 \mathrm{~h}$. The sample was precipitated into 300-350 mL methanol, stirred for $4 \mathrm{~h}$, and collected by vacuum filtration. Finally, the sample was dried in a vacuum oven overnight at 50 ${ }^{\circ} \mathrm{C} .{ }^{1} \mathrm{H}$ NMR $\left(300 \mathrm{MHz}, \mathrm{CDCl}_{3}\right) \delta 0.75-0.85\left(\mathrm{CH}_{3}\right.$ and $\left.\mathrm{CH}_{2}\right), 1.17-1.24\left(\mathrm{~m}, \mathrm{CH}_{2}\right), 1.32-1.42(\mathrm{~m}$, $\left.-\mathrm{C}(\mathrm{O})\left(\mathrm{CH}_{2}\right) \mathrm{CH}_{2}\left(\mathrm{CH}_{2}\right)_{2} \mathrm{O}-\right)$, 1.53-1.70 (br, $\mathrm{CH}$ and $-\mathrm{C}(\mathrm{O})\left(\mathrm{CH}_{2} \mathrm{CH}_{2} \mathrm{CH}_{2} \mathrm{CH}_{2} \mathrm{CH}_{2} \mathrm{O}-\right)$, 2.30 (t, $\left.\mathrm{C}(\mathrm{O}) \mathrm{CH}_{2}\left(\mathrm{CH}_{2}\right)_{4} \mathrm{O}-\right), 3.63\left(\mathrm{t}, \mathrm{CH}_{2} \mathrm{OH}\right), 4.05\left(\mathrm{t}, \mathrm{CH}_{2} \mathrm{O}-\mathrm{PCL}\right.$ and $\left.-\mathrm{C}(\mathrm{O})\left(\mathrm{CH}_{2}\right){ }_{4} \mathrm{CH}_{2} \mathrm{O}\right) ;{ }^{13} \mathrm{C}$ NMR $(75$ $\left.\mathrm{MHz}, \mathrm{CDCl}_{3}, 50{ }^{\circ} \mathrm{C}\right) \delta 19.1,20.6,21.5\left(\mathrm{CH}_{3}\right), 24.5\left(-\mathrm{C}(\mathrm{O})\left(\mathrm{CH}_{2}\right) \mathrm{CH}_{2}\left(\mathrm{CH}_{2}\right)_{2} \mathrm{O}-\right), 25.3$ ($\mathrm{C}(\mathrm{O})\left(\mathrm{CH}_{2} \underline{\mathrm{CH}_{2}}\left(\mathrm{CH}_{2}\right){ }_{3} \mathrm{O}-\right), 24.5,27.5,27.7,27.8,28.3 \quad\left(-\mathrm{C}(\mathrm{O})\left(\mathrm{CH}_{2}\right)_{3} \underline{\mathrm{CH}}_{2} \mathrm{CH}_{2} \mathrm{O}\right), 32.3$ 
( $\mathrm{CH}_{2} \mathrm{CH}\left(\mathrm{CH}_{2} \mathrm{O}-\mathrm{PCL}\right), 34.1\left(-\mathrm{C}(\mathrm{O}) \mathrm{CH}_{2}\left(\mathrm{CH}_{2}\right)_{4} \mathrm{O}-\right), 40.0\left(\underline{\mathrm{CH}}\left(\mathrm{CH}_{2} \mathrm{O}-\mathrm{PCL}\right), 45.5\left(\mathrm{CH}_{2}\right), 46.0\right.$

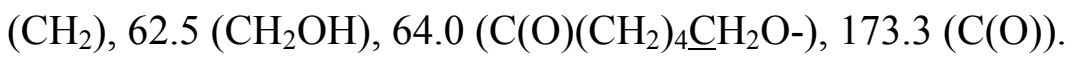

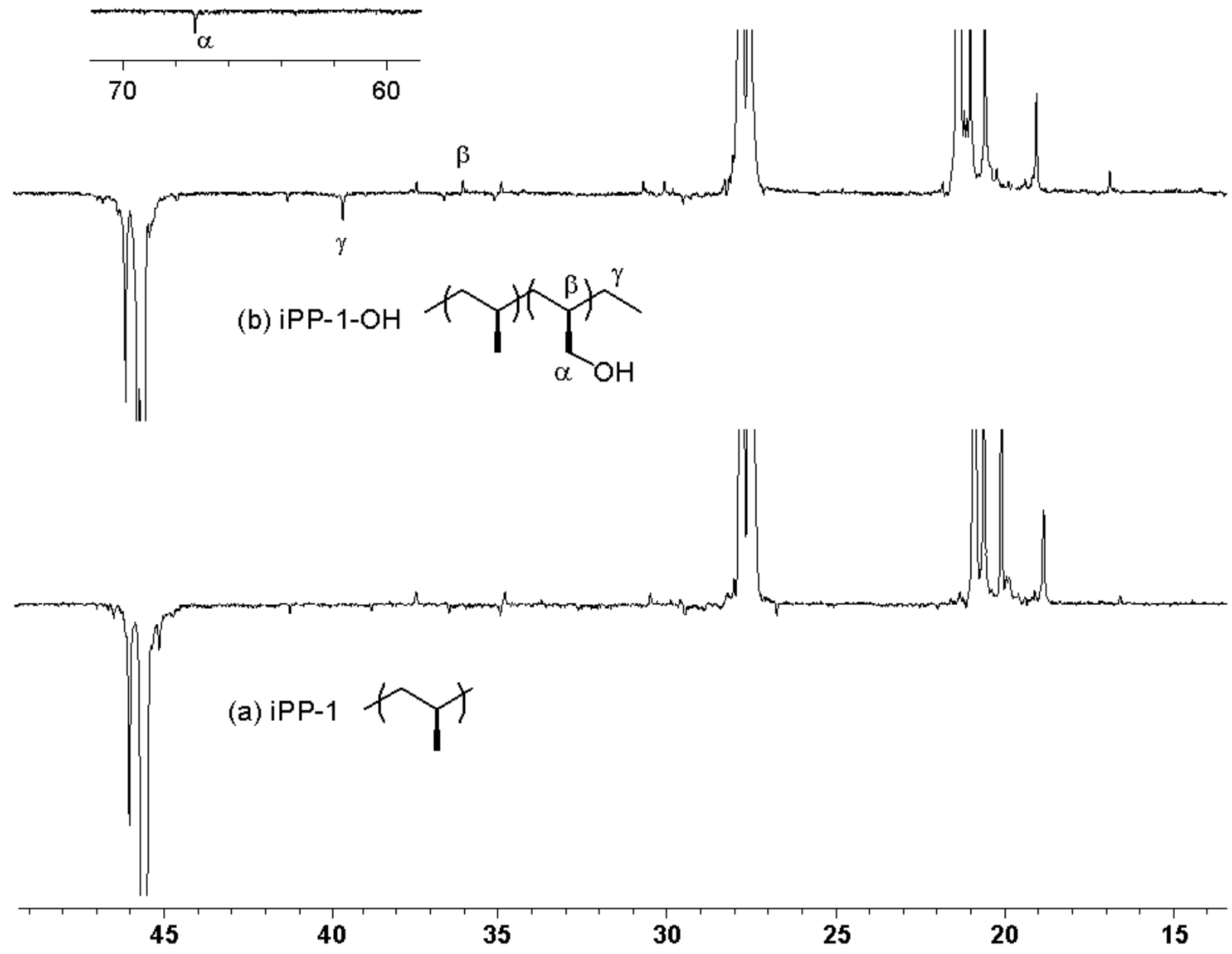

Figure S1. ${ }^{13} \mathrm{C}$ APT NMR spectra [delay time $=4 \mathrm{~s}$, number of transients $=10,500$ ] of (a) isotactic polypropylene $\left[60 \mathrm{mg} / \mathrm{mL}\right.$ in $70 / 301,2,4$-trichlorobenzene $/ \mathrm{C}_{6} \mathrm{D}_{6}$ at $\left.90{ }^{\circ} \mathrm{C}\right]$ and (b) $1 \%$ hydroxylated isotactic polypropylene $\left[60 \mathrm{mg} / \mathrm{mL}\right.$ in $\mathrm{CDCl}_{3}$ at $\left.60^{\circ} \mathrm{C}\right]$. 


\section{References}

(1) Gotro, J. T.; Graessley, W. W. Macromolecules 1984, 17, 2767.

(2) Zhongde, X.; Mays, J.; Xuexin, C.; Hadjichristidis, N.; Schilling, F. C.; Bair, H. E.;

Pearson, D. S.; Fetters, L. J. Macromolecules 1985, 18, 2560.

(3) White, C.; Yates, A.; Maitlis, P. M. In Inorganic Synthesis; Grimes, R. N., Ed., 1992; Vol. 29, pp 228.

(4) Bowyer, W.; Merkert, J. W.; Geiger, W. E. Organometallics 1989, 8, 191.

(5) Moseley, K.; Kang, J. W.; Maitlis, P. M. J. Chem. Soc. (A) 1970, 2875.

(6) Schmidt, S. C.; Hillmyer, M. A. Macromolecules 1999, 32, 4794. 